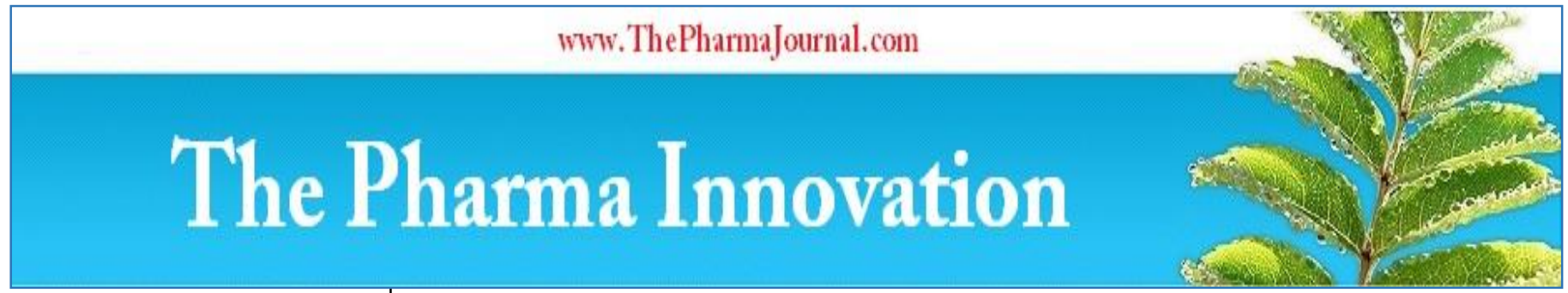

ISSN (E): 2277 - 7695

ISSN (P): 2349-8242

NAAS Rating: $\mathbf{5 . 2 3}$

TPI 2021; 10(4): 792-798

(C) 2021 TPI

www.thepharmajournal.com

Received: 01-02-2021

Accepted: 03-03-2021

\section{Vartika Singh}

Department of Fruit Science, College of Horticulture and

Forestry, ANDUA\&T,

Kumarganj, Ayodhya,

Uttar Pradesh, India

\section{Bhagwan Deen}

Department of Fruit Science, College of Horticulture and

Forestry, ANDUA\&T,

Kumarganj, Ayodhya,

Uttar Pradesh, India
Corresponding Author:

Vartika Singh

Department of Fruit Science,

College of Horticulture and

Forestry, ANDUA\&T,

Kumarganj, Ayodhya,

Uttar Pradesh, India

\section{Studies on changes in biochemical attributes during growth and development of ber (Zizyphus mauritiana Lamk.) fruit cv. (Narendra ber selection-2)}

\author{
Vartika Singh and Bhagwan Deen
}

DOI: https://doi.org/10.22271/tpi.2021.v10.i41.6055

\begin{abstract}
The Studies on changes in biochemical attributes during growth and development of ber (Zizyphus mauritiana Lamk.) fruit cv. (Narendra Ber Selection-2) was conducted during growing season of 201920. The fruits on tagged current season shoot were harvested at 21, 36, 51, 66, 81, 96, 111, 126, 141, 156, 171 and 186 days after fruit set. Samples were collected from Main Experiment Station, Horticulture and transported to the post graduate laboratory of Department of Fruit Science, College of Horticulture and Forestry, ANDUA\&T, Kumarganj, Ayodhya, Uttar Pradesh. The objective was to probe the pattern of biochemical changes in developing ber fruits. The outcomes reveal that total soluble solids increased from $1.04 \%$ to $17.94 \%$ during 186 days of fruit growth and development whereas acidity content continuously decreased and recorded $0.39 \%$ on $21^{\text {th }}$ day and $0.14 \%$ on $186^{\text {th }}$ day of growth and development. Ascorbic acid content increased from $3.29 \mathrm{mg} / 100 \mathrm{~g}$ to $90.26 \mathrm{mg} / 100 \mathrm{~g}$ of fruit. Reducing, Non-reducing and total sugar content significantly increased from $0.22 \%$ to $4.76 \%, 0.11 \%$ to $5.77 \%$ and $0.35 \%$ to $10.87 \%$, respectively. Moisture content showed decreasing trend and was maximum $71.12 \%$ on $21^{\text {st }}$ day and minimum $65.79 \%$ on $186^{\text {th }}$ day of observation. An abrupt decrease in chlorophyll content was recorded with growth and development of the fruit.
\end{abstract}

Keywords: Ber, Zizyphus mauritiana, NBS-2, fruit growth and development, arid fruit, dryland horticulture

\section{Introduction}

Ber (Ziziphus mauritiana Lamk.), the king of arid fruits, is a considerable minor hardy fruit crops symbolizing the production at a modicum cost. There are two major cultivated jujubesIndian jujube (Ziziphus mauritiana Lamk., 2n=48) and Common or Chinese jujube (Ziziphus jujube Mill., 2n =24). Genus Ziziphus comprises almost fifty species, out of which 18 to 20 are local to India (Pareek, 2001) ${ }^{[8]}$. It is evergreen, small (up to $15 \mathrm{~m}$ height), spiny tree with about $30 \mathrm{~cm}$ diameter trunk. Fruit is juicy drupe with $2.5 \mathrm{~cm}$ (diameter) and $4.5 \mathrm{~cm}$ (wide) and can be round, oval, ovate oblong or elliptical in shape. Ber is a perfect tree for arid as well as semiarid culture and one of the most nutritious fruit crop having medicinal as well as processing potential. The ber fruit is excellent source of proteins, carbohydrates, fibers, fats, TSS, ascorbic acid, antioxidants, total phenolics, reducing, and non-reducing and total sugars (Kumara et al., 2015) ${ }^{[6]}$. It can be consumed as fresh or can be used in processed forms such as powder, candies, murrabbah, jams and beverages. It can tolerate salinity, alkalinity and $\mathrm{pH}$ as high as 9.2and even waterlogged condition upto certain extent. This crop requires less water compare to other fruits therefore, suitable fordry land farming. Successful cultivation of ber can be done even in the most marginal ecosystem of tropics and subtropics (Pareek, 2001) ${ }^{[8]}$ and can tolerate extremely high temperature and are grown in region with maximum temperature of $39-42{ }^{\circ} \mathrm{C}$. The area under cultivation of ber is extending because of its unique ability to flourish even on neglected land, specific demand, hardy nature, good return, and Indian Government policies under National Horticulture Mission.

The studies on changes in biochemical attributes during growth and development are essential requirement to determine the maturity and harvesting time in order to maintain high nutritional quality, reduced post-harvest losses as well as better marketability. Therefore, the present investigation has been undertaken to observe the changes in biochemical attributes during growth and development of recent ber variety Narendra Ber Selection-2 (NBS-2). 


\section{Materials and Methods}

The present experiment was conducted at the Main Experiment Station of the Department of Fruit Science, Acharya Narendra Deva University of Agriculture \& Technology, India during the years 2019-20. The experiment was conducted on 27 years old uniform vigorous ber trees of variety Narendra Ber Selection-2 which received uniform cultural operation throughout the experiment. The trial was laid out with four replications. The four fruits from each replication were randomly picked up for biochemical analysis. The fruits were macerated to extract the juice for Total Soluble Solids (T.S.S.) estimation. The T.S.S. was recorded using $0-32 \%$ range ERMA hand refractometer at room temperature and corrected at $20^{\circ} \mathrm{C}$ with help of reference table (Ranganna, 2010) ${ }^{[14]}$. The $5 \mathrm{~g}$ of pulp was macerated with small amount of distilled water and filtered through muslin cloth for acidity estimation. The volume of filtrate was made up to $100 \mathrm{ml}$ with distilled water and $5 \mathrm{ml}$ aliquot was titrated against N/10 sodium hydroxide solution using phenolphthalein as indicator. The appearance of light pink colour was marked as end point. Ascorbic acid content was estimated by grinding $5 \mathrm{~g}$ fruit pulp with 3.0 per cent metaphosphoric acid and filtrate volume was made up to 50 $\mathrm{ml}$ with $3 \%$ metaphosphoric acid. The known amount of aliquot was titrated against 2, 6-dichlorophenol indophenol dye solution till the appearance of light pink color. The ascorbic acid content was calculated with help of formulae and expressed as $\mathrm{mg}$ ascorbic acid/100 $\mathrm{g}$ of fruit pulp (A.O.A.C., 1975) ${ }^{[1]}$. To determine the reducing sugars, 5g pulp was crushed with distilled water and volume of filtrate was made up to $100 \mathrm{ml}$ with distilled water. $5 \mathrm{ml}$ aliquot was mixed with $5 \mathrm{ml}$ of each Fehling's solution 'A' and 'B' (Lane and Eynone, 1923) and titrated against $1.0 \%$ glucose solution in boiling condition with few drops of methylene blue indicator upto appearance of light brick colour. The blank sample was also titrated against $1 \%$ glucose and reducing sugars content was calculated with help of formulae (Ranganna, 2010) ${ }^{[14]}$. Then two drops of HCL was added to aliquot and left for overnight to estimate total invert sugars. The reducing sugars were substracted from total invert sugar and result was multiplied with factor 0.95 to get non-reducing sugar. The sums of reducing and non-reducing sugars were expressed as total sugar.

The green layer of peel was taken from fruit and chopped into fine pieces. Chlorophyll was extracted with 80 per cent acetone following the procedure of Witham et al., (1971). The intensity of color was recorded at $663 \mathrm{~nm}$ wave length and calculated chlorophyll content expressed as mg per $100 \mathrm{~g}$ of peel. To record moisture content in fruit, the fruit were dried into oven at $60{ }^{\circ} \mathrm{C}$ to constant weight then moisture content was calculated and expressed in percent.

\section{Statistical analysis}

The data on chemical attributes of fruit were recorded and analyzed statistically applying the analysis of variance procedures outlined by Panse and Sukhatme (1967) ${ }^{[9]}$ and the analyzed data and graph were used to interpret the results.

\section{Results and Discussion}

Table 1: Changes in biochemical attributes during growth and development of ber fruit cv. NBS-2

\begin{tabular}{|c|c|c|c|c|c|c|c|c|c|}
\hline \multicolumn{2}{|c|}{$\begin{array}{l}\text { Interval } \\
\text { (days) }\end{array}$} & $\begin{array}{c}\text { Total } \\
\text { Soluble } \\
\text { Solids (\%) }\end{array}$ & $\begin{array}{c}\text { Acidity } \\
(\%)\end{array}$ & $\begin{array}{l}\text { Ascorbic acid } \\
\text { (mg/100g) }\end{array}$ & $\begin{array}{c}\text { Reducing } \\
\text { sugars }(\%)\end{array}$ & $\begin{array}{l}\text { Non-reducing } \\
\text { sugar }(\%)\end{array}$ & $\begin{array}{c}\text { Total } \\
\text { sugars }(\%)\end{array}$ & $\begin{array}{c}\text { Moisture } \\
(\%)\end{array}$ & $\begin{array}{l}\text { Total chlorophyll } \\
\text { (mg/1oog peel) }\end{array}$ \\
\hline 21 & \multirow{3}{*}{ October } & 1.04 & 0.39 & 3.29 & 0.22 & 0.11 & 0.35 & 71.12 & 39.01 \\
\hline 36 & & 1.43 & 0.36 & 3.44 & 0.27 & 0.33 & 0.60 & 70.20 & 38.90 \\
\hline 51 & & 1.50 & 0.32 & 4.30 & 0.31 & 0.66 & 0.99 & 69.82 & 38.03 \\
\hline 66 & November & 2.48 & 0.30 & 5.61 & 0.45 & 0.96 & 1.34 & 69.80 & 36.06 \\
\hline 81 & & 2.98 & 0.24 & 5.84 & 0.76 & 1.06 & 2.04 & 69.36 & 35.31 \\
\hline 96 & \multirow{2}{*}{ December } & 3.25 & 0.22 & 9.90 & 1.29 & 1.45 & 2.74 & 69.52 & 31.23 \\
\hline 111 & & 4.38 & 0.18 & 17.21 & 1.42 & 1.50 & 3.32 & 69.32 & 28.48 \\
\hline 126 & \multirow{2}{*}{ January } & 10.10 & 0.17 & 23.25 & 1.67 & 1.85 & 3.67 & 68.76 & 27.16 \\
\hline 141 & & 15.05 & 0.16 & 32.75 & 2.56 & 2.75 & 5.70 & 68.80 & 23.95 \\
\hline 156 & \multirow{2}{*}{ February } & 15.58 & 0.15 & 49.37 & 3.57 & 2.93 & 7.56 & 67.88 & 22.08 \\
\hline 171 & & 17.29 & 0.14 & 70.96 & 4.19 & 3.96 & 9.64 & 67.49 & 20.50 \\
\hline 186 & March & 17.94 & 0.14 & 90.26 & 4.76 & 5.77 & 10.87 & 65.79 & 12.36 \\
\hline SEm \pm & & 0.11 & 0.00 & 0.08 & 0.00 & 0.01 & 0.04 & 0.11 & 0.01 \\
\hline \multicolumn{2}{|c|}{$\mathrm{CD}$ at $5 \%$} & 0.34 & 0.01 & 0.22 & 0.01 & 0.01 & 0.11 & 0.32 & 0.05 \\
\hline
\end{tabular}

\section{Total soluble solids}

The data pertaining to fruit length of various stages of fruit growth are presented in Table-1 and showed pictorially in Fig. 1.1. Total soluble solids content of ber fruit increased continuously during entire period of growth and development. The hydrolysis of polysaccharides into sugar and synthesis of other water solubles results an increase of total soluble solids. Patil and Shanmugasundaram, (2015) [10] also reported significant increase in TSS toward progressed developmental stages of banana fruits. Similar observation was reported by Sahu et al., (2018) ${ }^{[16]}$ on fruit growth \& development of ber (Ziziphus mauritiana Lamk.). 


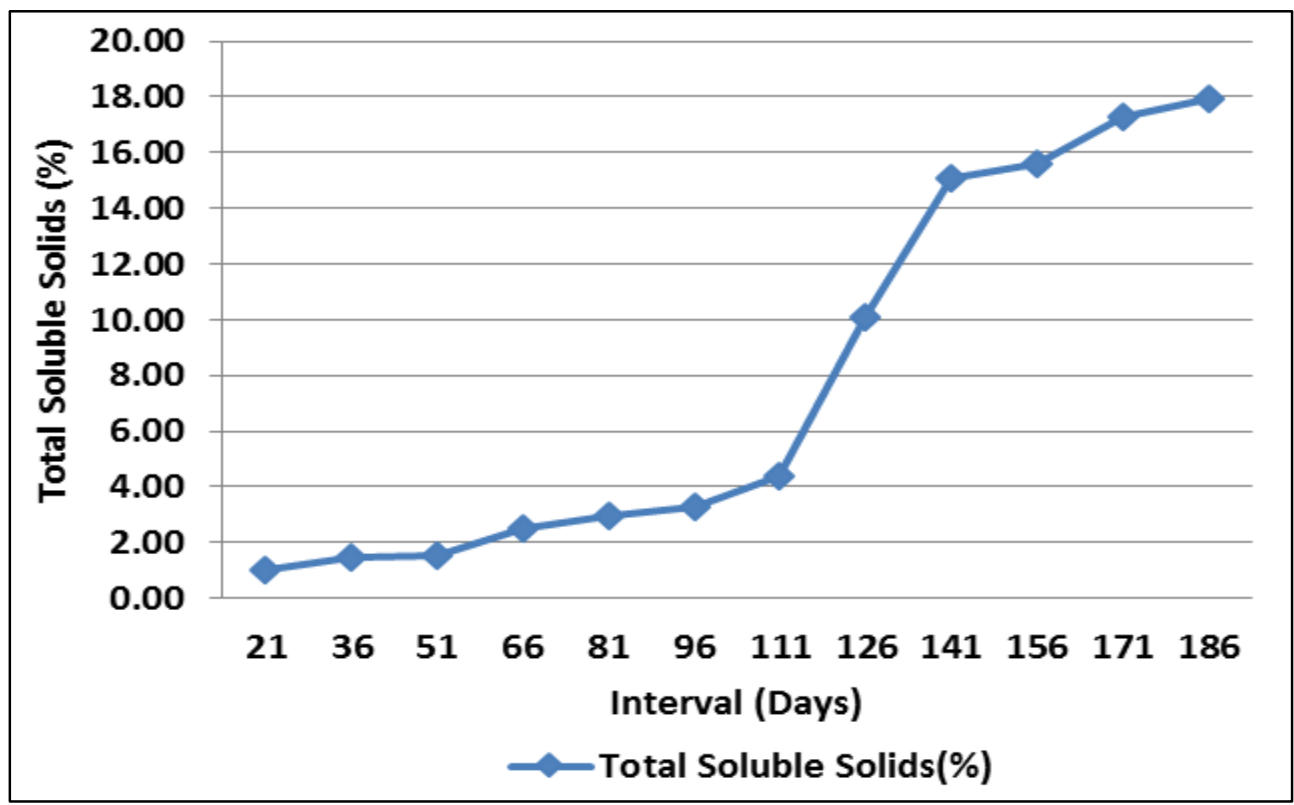

Fig 1: Changes in Total Soluble Solids during growth and development of ber fruit cv. NBS-2

\section{Acidity}

Data in Table-1 showed that the acidity content of ber fruit continued to decrease throughout fruit growth and development (Fig. 1.2) after fruit setting, which might be due to the reason that available organic acids utilized at faster rate during the respiratory process (Bal et al., 1995) ${ }^{[2]}$. Similar observation was reported by Islam et al., (2015) ${ }^{[5]}$ who reported that total acidity decreased gradually from 90 days to 130 days of ber fruit setting.

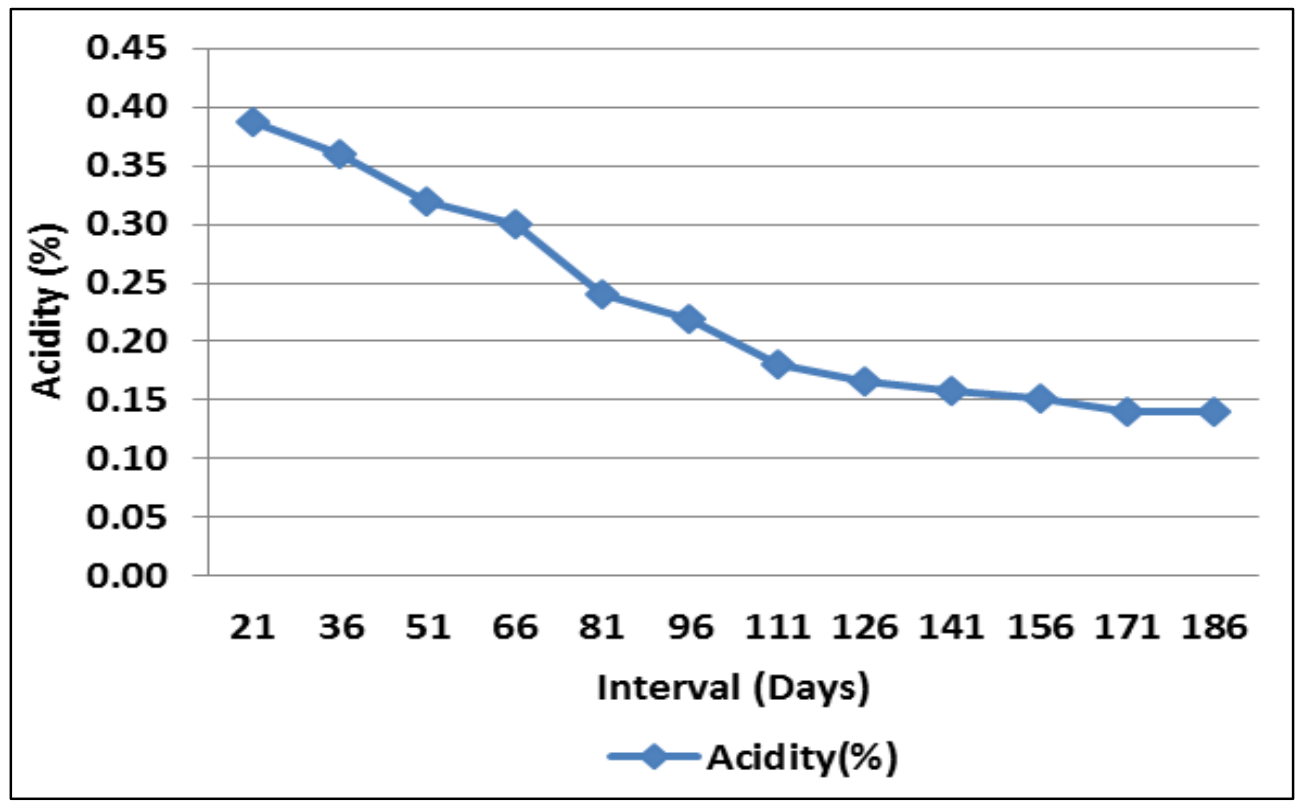

Fig 2: Changes in Acidity content during growth and development of ber fruit cv. NBS-2

\section{Ascorbic acid:}

It is clear from data of Table-1 and Fig.1.3 that the ascorbic acid content of fruits was continuously increased during growth and development. The accumulation and synthesis of glucose-6-phosphate reserved as a precursor of ascorbic acid synthesis in fruit (Marton, 1970) might be the reason of ascorbic acid content increase in the fruits during growth and development. The results were in line with the findings of Pathare et al., (2016) ${ }^{[11]}$ who observed an increasing trend in ascorbic acid content of cultivar Mehrun-khedi, Mehrun and M.P.K.V. ber fruits from its setting till maturity. 


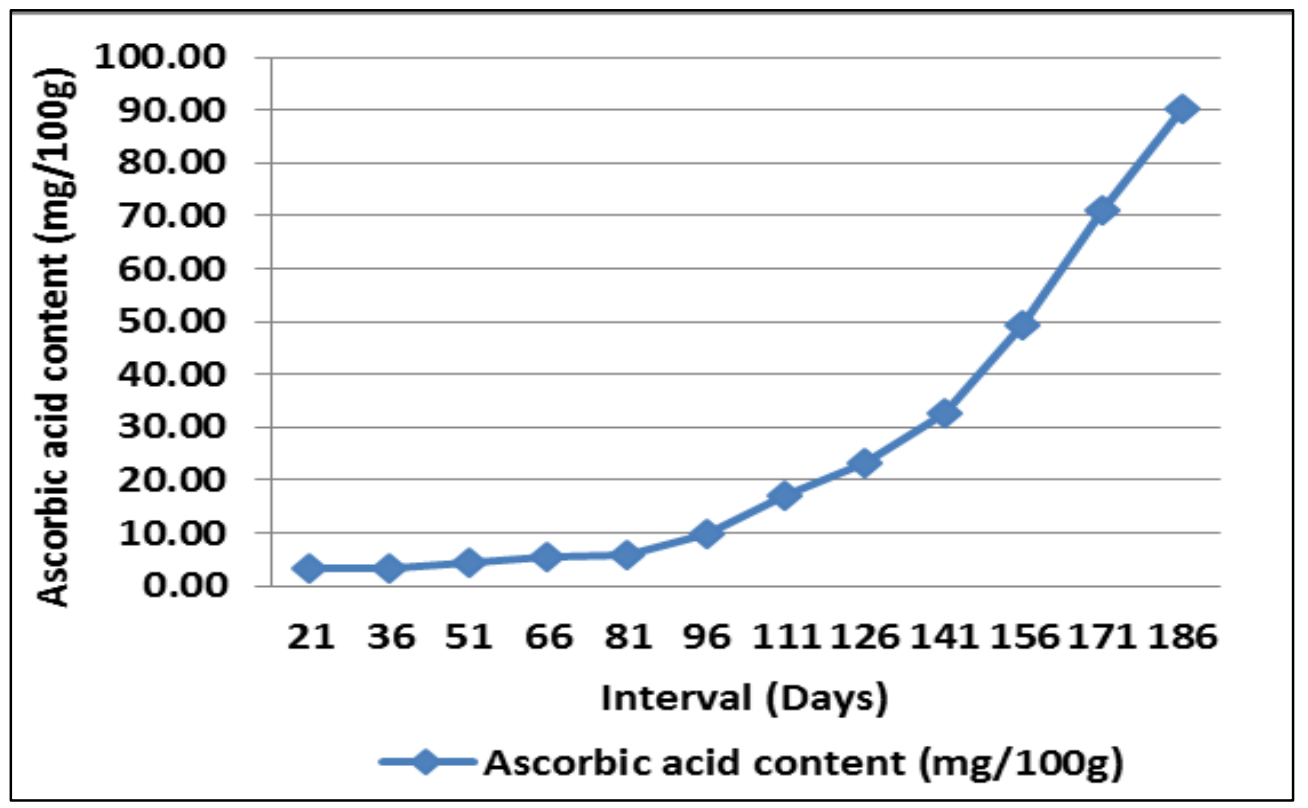

Fig 3: Changes in Ascorbic acid content during growth and development of ber fruit cv. NBS-2

\section{Reducing sugars}

The data presented in Table-1 pertaining to reducing sugars content at various stages of fruit growth and development depicted in Fig. 1.4. The gradual increase in reducing sugars was recorded that might be due to conversion of polysaccharides and non-reducing sugar in to reducing sugars during growth and development of fruit. Sahu et al., (2018) [16] also observed similar trend in reducing sugar during growth and development of ber fruits. They further reported that reducing sugar of ber fruits influenced by different genotypes.

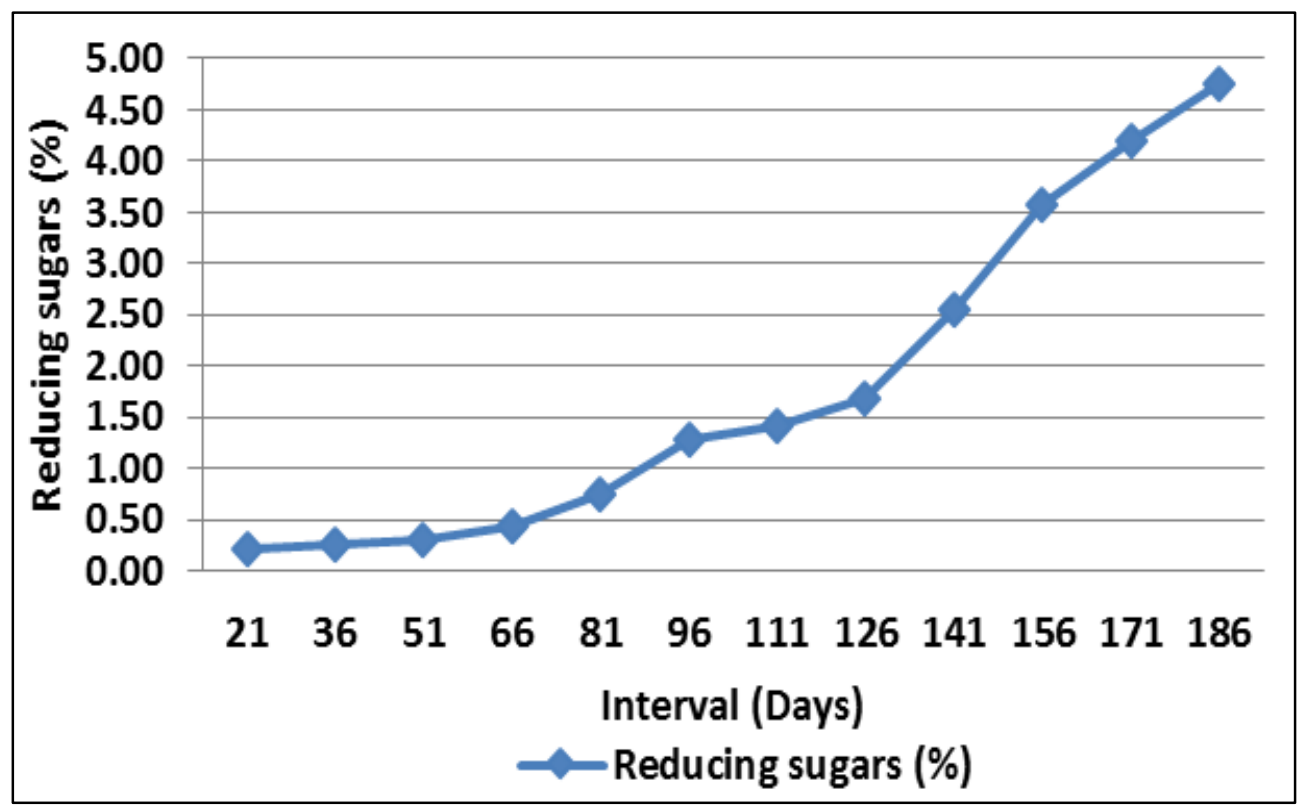

Fig 4: Changes in Reducing sugars during growth and development of ber fruit cv. NBS-2

\section{Non-reducing sugar}

It is clear from data of Table-1 that the non-reducing sugar content in ber fruit increased continuously from fruit set till maturity (Fig.1.5) which could be due to hydrolysis of starch into sucrose when fruit proceeded towards maturity and ripening. The finding agrees with Pandey and Deen (2018) [12]. 


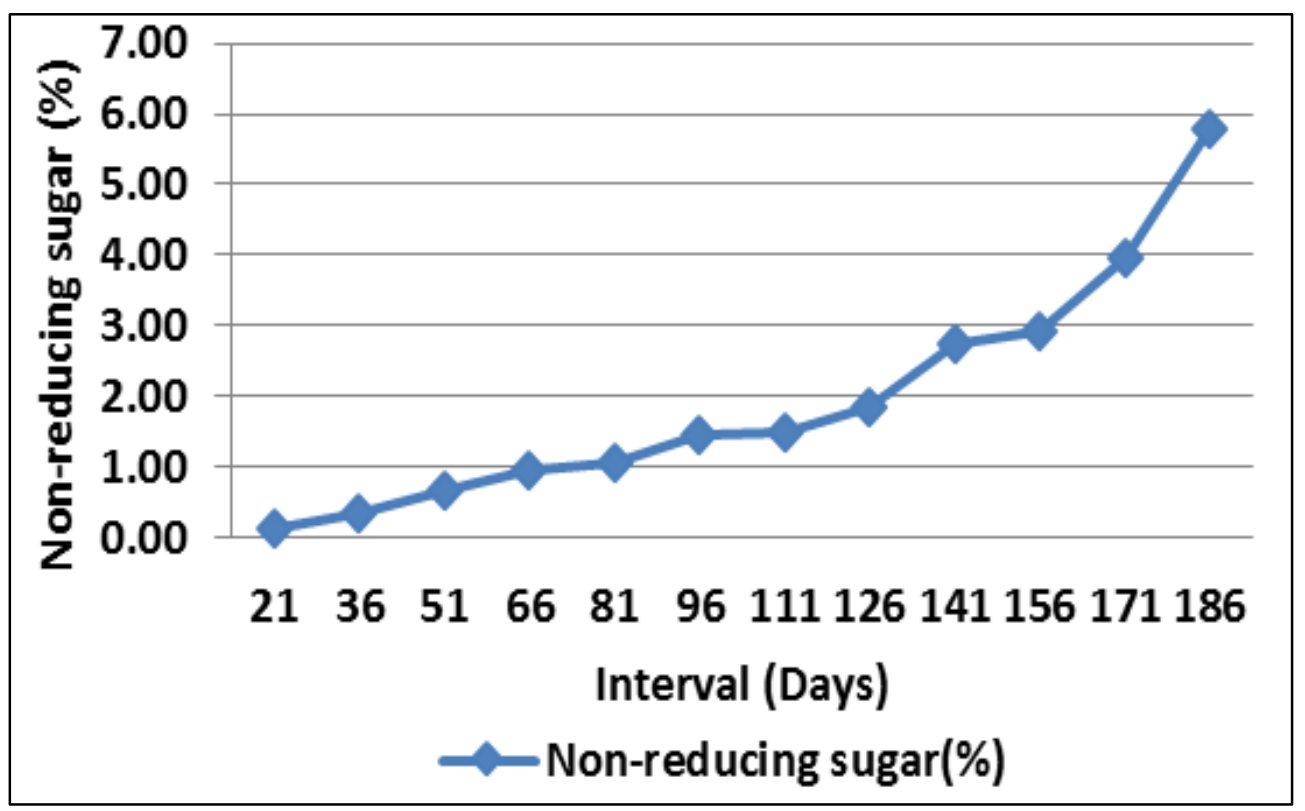

Fig 5: Changes in Non-reducing sugar during growth and development of NBS-2

\section{Total sugars}

Continuous significant increase was observed in total sugars content of ber fruit during entire growth and development (Fig.1.6). Conversions of polysaccharides into sugars contribute to total soluble solids and reducing sugars which ultimately increases in total sugar content.
Radha and Rajasekhar (2014) ${ }^{[13]}$ also found increased total sugar content continuously with advancement of growth and maturity in sapota cultivars viz., PKM-1, PKM-3, DSH-1, DSH-2, Pala, Kalipatti, Cricket ball, Singapore, Kirthibarthi and Virudhnagar.

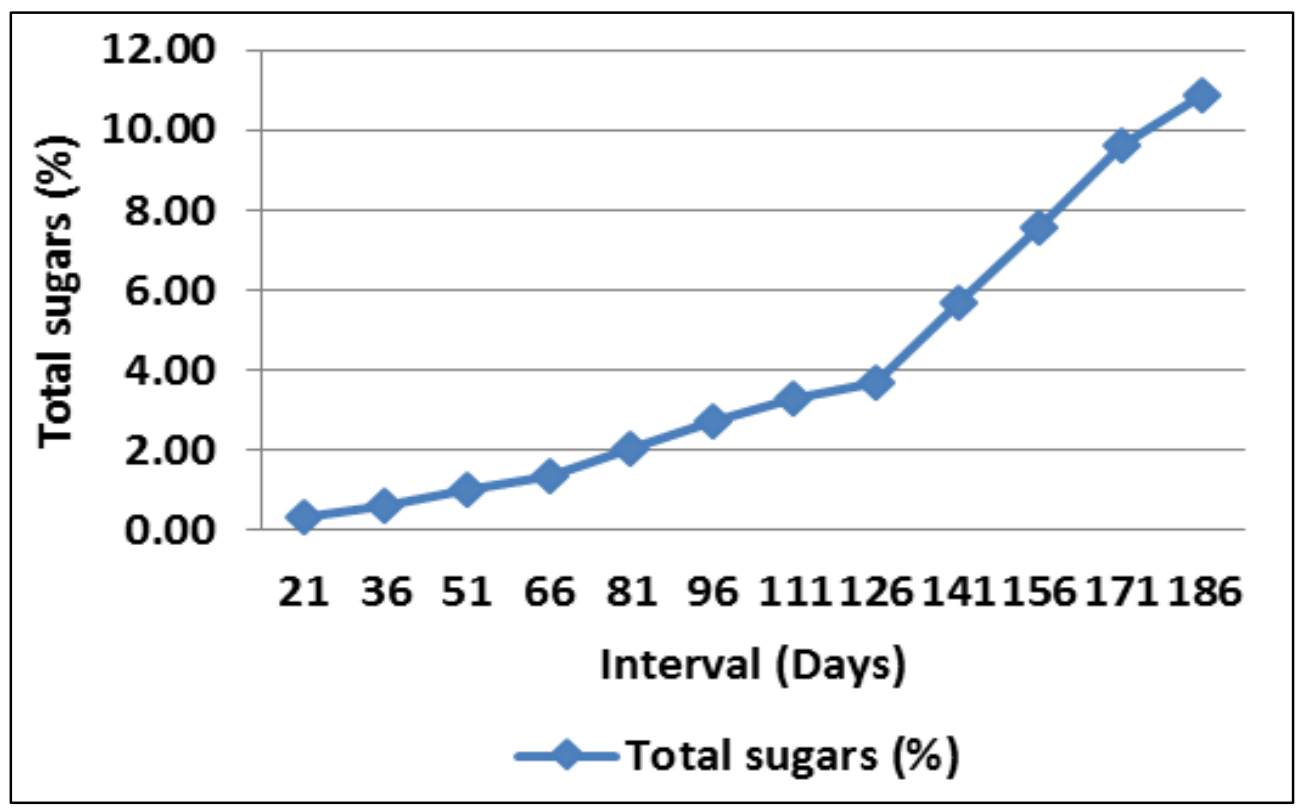

Fig 6: Changes in Total sugars content during growth and development of NBS-2

\section{Moisture}

The moisture content continued to decrease (Fig. 1.7) throughout the fruit growth and development which might be because of accumulation of more total solids in fruits. The moisture content was maximum $71.12 \%$ on $21^{\text {st }}$ dayand minimum $65.79 \%$ on $168^{\text {th }}$ day after fruit setting.

Mukesh et al., (2016) reported similar results and observed decreasing trend in percentage of moisture content with advancement of ripening of jujube fruits cvs. Kaithali, Umran and Ponda. 


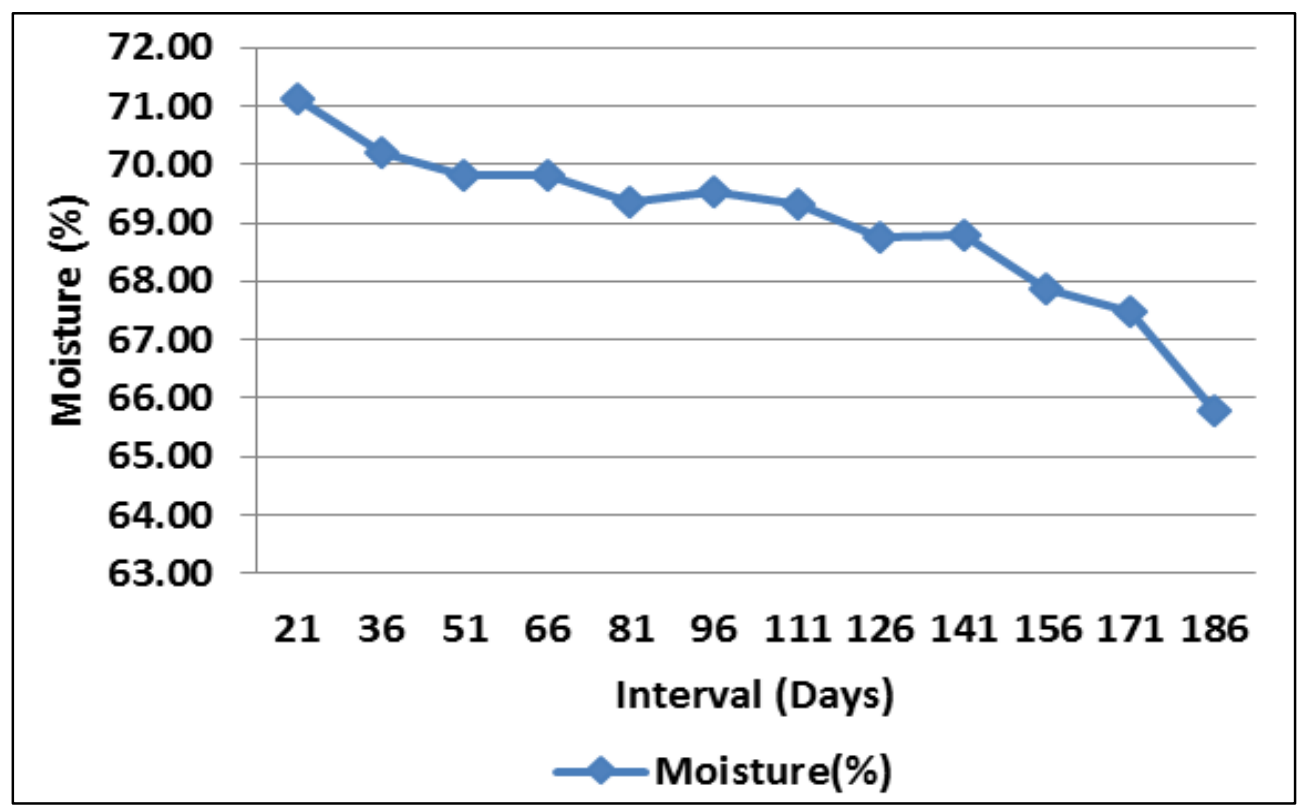

Fig 7: Changes in Moisture content during growth and development of NBS-2

\section{Total Chorophyll}

An abrupt significant decreasing trend (Fig.1.8) in chlorophyll content of fruit was recorded with growth and development. Decrease in chlorophyll content might be result of degradation of chlorophyll and synthesis of other pigments in the fruit. Sharma et al., (2008) [15] and Ezhilarasi and Tamilmani, (2009) [3] were also reported similar findings which are in support of present result.

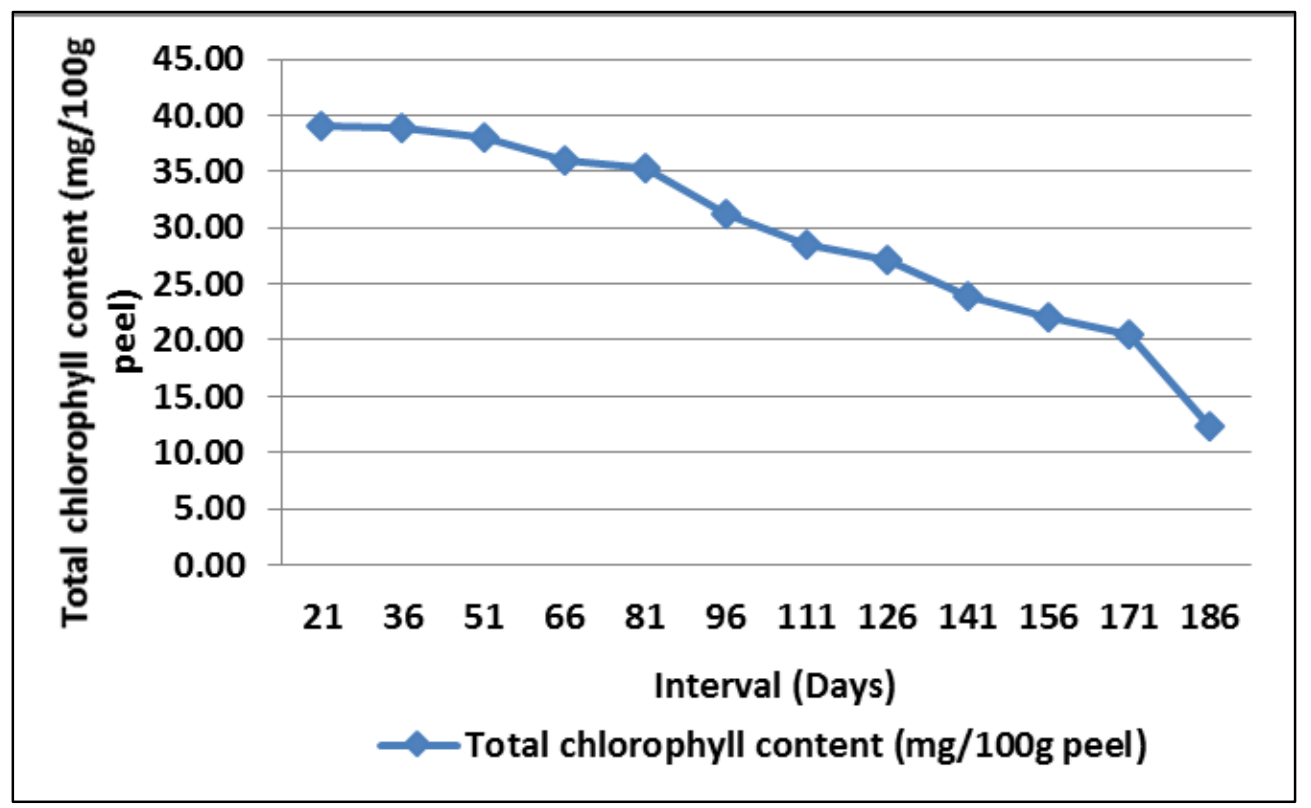

Fig 8: Changes inTotal chlorophyll content in ber fruit cv. NBS-2

\section{Conclusion}

The various biochemical attributes viz. total soluble solids, acidity, ascorbic acid, reducing sugars, non-reducing sugar, total sugars, moisture and total chlorophyll content of Narendra Ber Selection-2 fruits were investigated since $21^{\text {st }}$ October to $15^{\text {th }}$ March under Northern Indian agro-climatic conditions at an interval of 15 days during growth and development period of fruit. The total soluble solids, ascorbic acid, reducing sugars, non -reducing sugar and total sugars contents of fruit were increased with the growth and development whereas titratable acidity, moisture, and total chlorophyll showed decreasing trend throughout growth and development.
References

1. AOAC. Official Methods of Analysis.13 $3^{\text {th }}$ ed., Association of Official Analytical Chemists. Washington D.C., USA 1980.

2. Bal JS, Kahlon PS, Jawanda JS, Randhawa JS. Studies on artificial ripening of ber fruits (Ziziphus mauritiana Lamk.). Phala Samaskaran 1995;1(2):325-333.

3. De Candolle, A. Bibelot heque Scientific International 1886;43paris:385.

4. Ezhilarasi, Tamilmani C. Influence of paddy husk on the ripening of fruit of Zizyphus mauritiana Lamk. Journal of Agricultural and Biological Science 2009;4(6):29-42.

5. Islam MN, Molla MM, Nasrin TAA, Uddin ASMM, Kobra K. Determination of maturity indices of ber (Ziziphus mauritiana Lamk.) var. BARI-Kul-2. 
Bangladesh Journal of Agricultural Research 2015;40(1):163-176.

6. Kumari S, Bhat D, Wali VK, Bakshi P, Jasrotia A. Physico-chemical studies of different ber (Ziziphus mauritiana Lamk.) germplasm under rainfed condition of Jammu. International Quarterly Journal of Life Sciences the Bioscan 2015;10(3):1427-1430.

7. NHB. Area and Production of Horticulture crops for 2018-19.Retrieved from http://nhb.gov.in/Statistics.aspx. 2018.

8. Pareek OP. Fruits for the Future 2: Ber. International Centre for Underutilised Crops, University of Southampton, Southampton, UK 2001.

9. Panse VG and Sukhatme PV. Statistical method of Agricultural Workers, ICAR Publication. New Delhi 381.

10. Patil SK and Shanmugasundaram S. Physicochemical changes during ripening of Monthan banana. International Journal of Technology Enhancement and Emerging Engineering Research 2015;3(02):2347-4289.

11. Pathare SA, Rohokale GY, Abhang AR. Changes in Ascorbic Acid content during development and maturity in Ber fruits (Ziziphus mauritiana Lamk) cvs. Mehrun Khedi, Mehrun and MPKV. International Journal of Scientific Research 2016;5(1):2277-8179.

12. Pandey S, Deen B. Studies on the Pattern of Changes in Biochemical Constitutes of Ber (Zizyphu smauritiana Lamk.) Fruit cv. Narendra Ber Selection-1. International Journal of Current Microbiology and Applied Sciences 2018;7(4):636-640.

13. Radha G, Rajasekhar M. Studies on fruit growth and development and standardization of maturity indices in different sapota (Manilkara achras Mill.) Fosberg cultivars. M.Sc. (Horticulture) Thesis, Dr. Y. S. R. Horticultural University, Horticultural Research Station, Venkataramannagudem, West Godavari district, Andhra Pradesh 2014.

14. Rangana S. Hand Book of Analysis and Quality Control for Fruit and Vegetable Products. Tata McGraw-Hill Education Private Ltd., New Delhi, India 2010, 105-201.

15. Sharma S, Sharma RK, Siddiqui S, Goyal RK, Sharma JR, Kumar S. Physico-chemical changes during growth and development of ber (Zizyphus mauritiana Lamk.). Haryana Journal of Horticultural Sciences 2008;37(12):57-59.

16. Sahu K, Pandey CS, Pandey SK, Verma R. Studies on physical changes during fruit growth and development of different genotypes of ber (Zizyphus mauritiana Lamk). International Journal of Current Microbiology and Applied Sciences 2019;8(2):3325-3332. 